\title{
An Act of Euthanasia to an Act
}

Dharmapuri Selvakumar Madhumitha*

B.Com LLB (Hons), Final year student, Tamil Nadu National Law University, Tamil Nadu, India

DOI: $10.36348 /$ SIJLCJ.2019.v02i09.003 $\quad$ | Received: 06.09.2019| Accepted: $23.09 .2019 \mid$ Published: 30.09 .2019

*Corresponding author: Madhumitha DS

\section{Abstract}

Euthanasia is a much debated concept around the world. It involves a human's right to take way his life or have a choice of living the life. Art.21 guarantees the right of life and liberty also including human dignity as a fundamental right and human right. Does a person have a right not to live is the question of the hour.The study would be touch upon the history of Human right of a man in India, the justification to euthanasia's legality or illegality while studying euthanasia in other jurisdictions as well thereby analysing the concept of life and death as a Constitutional right and a human right in formation of legislation to control and guide euthanasia and the principles by which it is governed and the policy towards an effective legislation in India while taking guidance from Netherlands and Belgium Court's statement in validifying the act of passive euthanasia.

Keywords: Euthanasia, Crime, Human Rights, Regulation, Legislation.

Copyright @ 2019: This is an open-access article distributed under the terms of the Creative Commons Attribution license which permits unrestricted use, distribution, and reproduction in any medium for non-commercial use (NonCommercial, or CC-BY-NC) provided the original author and source are credited.

\section{EUTHANASIA}

In the world of death and crimes we often differ our choices and opinions when it comes to mercy killing, death by voluntary choice. Some people view life to be a sacred concept given by god, they have their right to life embedded under Art.21 of the constitution of India but that doesn't mean that they have the right to kill themselves taking away their own right, such right belong only with the state. Why did Euthanasia come in as a concept?

The word originated from a Greek word: which means Good death [ $\left.{ }^{1}\right]$. When a person takes away his own life, it is said to be a suicide, but when others take it for him, then such would be mercy killing when it is done with consent. This concept of euthanasia applies when one person is ill or bedridden, that there is no point in living afterwards and totally dependent on others to live. The decision of a person being terminally ill who would come under the category of mercy killing would ultimately rests with the doctors in charge of the patient. It usually resorted when the doctor can determine a patient's last minutes that they can confirm it is better to die rather than live like this. Hidden meaning behind euthanasia is peaceful death; it is given to a person so that the ill can die with dignity.

Right to die with dignity has been the emerging concept of law in the $21^{\text {st }}$ century. It was much difficult for the doctors to assist a death of a person, voluntarily and with consent. The sanction was given for a legislation to be passed in some countries based on its constitution, what the people needed and democratically accounted for in demand, example of such would be Netherlands and Belgium[ $\left.{ }^{2}\right]$. Some countries even though the demand is high have only recognised the concept of euthanasia but haven't passed a legislation to govern the act. Switzerland for example recognises physician assisted suicide and there is a ban to euthanasia and there is India, which recognizes passive euthanasia and not active euthanasia Different Countries recognize based on their wide interpretation of Right to life under the constitution or Human Rights law and docket control scope of Judicial Decisions. Some others consider it illegal due to the event that it will constitute murder or manslaughter, example of one such country would be UK, while in US active euthanasia is illegal while physician assisted suicide is

\footnotetext{
${ }^{2}$ Sigrid Dierickx,Euthanasia Practice in Belgium, A Popular based evaluation of trends and currently

debated issues,p.19.

${ }^{1}$ Suresh Bada Math and Santhosh K.Chatruvedi, Euthanasia: Right to Life v. Right to die(Dec,2012), Online:NCBI.
} 
legal in few states such as Washington, Oregon, New jersey and so.

In this Article, there is going to be a study of euthanasia in three parts. The first part dealing with the different types of euthanasia and understanding the difference between an active, passive, and assisted suicide as it varies in different countries based on their history with the legality. The second part sheds light on two countries in which euthanasia was first legalised, Netherlands and Belgium. The study would be slightly towards their history in formation of legislation to control and guide euthanasia and the principles by which it is governed. The third part would analyse on the policy towards an effective legislation in India while comparison and taking guidance from Netherlands and Belgium along with the Court's statement in validifying the act of passive euthanasia.

By knowing about how the procedure is carried out in Belgium and Netherlands we can know how to create and guide a legislation making to bring Euthanasia under the government control in India. The legality and the moral principle under which euthanasia is granted can also be said to influence the Courts in India. The kind of analysis that I embark upon is not to find the correct or right form of legislation or to bring a right procedure to guide euthanasia but to give a new perspective and methods in which legal order can be made to understand the freedom and responsibility that is undertaken by the patients and the doctors in termination of life under two different legislation and their legal sanctity through different case laws. Comparative constitutional law as said by Sacco, $1991\left[^{3}\right]$ is to acquire knowledge of different laws,rules,legal institutions and structure to make a selfreflection and betterment of who we are and what we could be in lieu of just and good principles $\left[{ }^{4}\right]$. What makes these two Countries to lead the chart of example is that it is proceeds from the similar humane values and principles demanded from the people in both the societies.

A new perspective can lead to a constitutional conversation on the legal structure and the principle of morality and dignity upon which euthanasia is legalised by statutes and on the moral principle by which dignified death is allowed. The perspective differs here in the basic right of human being to request termination of life and end his life in a dignified way. Constitutional guidance from multiple nations is a way of round-trip

\footnotetext{
${ }^{3}$ Antonia Baraggia, Challenges in Comparative Constitutional Law Studies: Between Globalization and constitutional Tradition. Special issue-comparative Law, Law and Method, (Oct 2017), Online: lawandmethod.

${ }^{4} \mathrm{R}$ Hirschl, comparative Matters: Response to interlocutors,,(2014). Boston University Law Review, p.139
}

comparison which allows jurists to come back home and give solutions with different knowledge obtained through different understandings of law in other countries $\left[{ }^{5}\right]$. The comparison may give way to right direction of thought and action in formation of legislation for structuring the procedure of Euthanasia and open our eyes to new changes and edges on how a law could be transformed. So that in future cases, when the Judges are called to answer a question of law or popular sanction in the Court, the institution can have a text to interpret and guide the decision making process, thereby granting legitimacy to the judgement. It may foster judicial dialogues and suggest various proposals to the legislators on how to face the challenges.

Through the understandings the legislators are free to make use of the knowledge obtained through round trip comparison or just brush it aside $\left[{ }^{6}\right]$. The law makers mostly choose the system which is useful for governance in context of cultural, political, social, economic situation influenced by the democratic system and institutions. It creates a dialogue mostly in inter parliamentary comparison for the first stage of legislative making ${ }^{7}$ and plays a major role in legislative intent while formation of a legislation leading to a domestic law which may be used to interpret the constitution in a different way by the Judges. The legal tradition and norm of the domestic land often choose the legislative model $\left[{ }^{8}\right]$.

\section{Euthanasia and its types}

Before we head into the main content of the project it is important to understand different types of Euthanasia and how it is performed. First important type of Euthanasia that is debated around the world and is opposed in many countries amounting to murder and no morality would be Active Euthanasia- it is an act by the medical professionals deliberately that causes a person to die, the causation of death can be by injecting a lethal dose into a person's body that quickens death in minutes [ $\left.{ }^{9}\right]$. As per doctor Dr. Marc Van Hoey who is a general practitioner in Belgium, explains that the person has to be suffering from two things to request termination of life: "Constant and Unbearable pain" the

\footnotetext{
${ }^{5}$ Supra Note. 2

${ }^{6}$ Round Trip Comparison is where the jurists go around the world studying, understanding and analysing the provisions, articles in different jurisdictions.

${ }^{7}$ Supra Note.2, by De Vergottini,2015, in Tradizioni costituzionali e vincoli alla comparazione. Diritto Pubblico Comparato ed Europeo p.957 as stated by Antonia Baraggia.

${ }^{8}$ Monateri, Pier Giuseppe, Methods in Comparative Law: An Intellectual Overview, P.7,. (Sept 25,2012)Online:SSRN.

${ }^{9}$ BBC, Active and Passive Euthanasia, (2014) Online: BBC, , See also, Dr.Marc Van Hoey, The Right to die in Belgium: An inside look at the world's most liberal Euthanasia, (Jan 15,2015), Online: PBS Newshour
} 
second is "Incurable disease" and for which a person requests a death. Passive Euthanasia has to with omission of an act due to which a patient dies. It maybe stopping of the respiratory system, stopping extension of life by disconnecting tubes and drugs $\left[{ }^{10}\right]$. Voluntary Euthanasia is an act of euthanasia done by another with the consent of the patient who wishes to die. Involuntary euthanasia where life would be terminated despite the consent of the patient to live. Non-Voluntary Euthanasia would be when a person is not in an active mind or a position to give his consent such as incompetent to make a decision and is unable to express, mentally ill or abnormalities as an issue $\left[{ }^{11}\right]$.

Next comes the concept of Physician assisted suicide, it is not same as active euthanasia but it is similar where there is physician's assistance to a person's death, prescription is given to the patient to be self-administered thereby causing death [ ${ }^{12}$ ]. Netherlands is one of the country in which physician assisted suicide is allowed openly since 2002 but it is to be noted that the courts permitted it since $1984\left[{ }^{13}\right]$.

\section{Euthanasia as a Human Right}

Human beings merely being a human being the human rights are conferred upon them, most llikely known as natural rights. It is the freedom, liberty, protection against others in a package called rights. Certain human rights are also fundamental rights such as Right to life, Right from discrimination etc. $\left[{ }^{14}\right]$ this right to life is not only embedded here in UDHR but also in International Covenant on civil and Political Rights otherwise known as ICCPR under Art. $6\left[{ }^{15}\right]$. The Human Rights Act, 1998 have considered that if a person cannot relive himself of a pain which is unbearable by him is an inhuman and degrading treatment, such a treatment is forbidden $\left[{ }^{16}\right]$. Here comes the merging concept of Euthanasia, even though there maybe people who protest against Euthanasia, the supporters do agree that the Court or the legislation

\footnotetext{
${ }^{10}$ E Garrard, S Wilkinson,Passive Euthanasia,BMJ Journals, Vol.31,Issue2.

${ }^{11}$ Chao DVK, Chan NY and Chan WY, Euthanasia revisited, Family Practice(2002) Vol.19, Issue 2, P: 128-134,

${ }^{12}$ Ewan C. Goligher, E. Wesley Ely, Daniel P. Sulmasy, Jan Bakker, John Raphael, Angelo E. Volandes, Bhavesh M. Patel, Kate Payne, Annmarie Hosie, Larry Churchill, Douglas B. White, and James Downar, Physician assisted suicide and Euthanasia in the Intensive care unit: A dialogue on core Ethical Issues, NCBI-PMC (Feb 1,2018) Online:NCBI

${ }^{13}$ Deccan Herald, Euthanasia illegal in many Countries, (Mar 7,2011) Online: Deccan Herald

${ }^{14}$ Universal Declaration of Human Rights, 1948

${ }^{15}$ Article 6 "Every human being has the inherent right to life. This right shall be protected by law. No one shall be arbitrarily deprived of his life".

${ }^{16}$ European Convention on Human Rights, Art.3.
}

should have proponents and elaborate on the circumstances in which a person is required the assistance to die and the fact of mercy killing will not be punished. The opposition for legalization of Euthanasia argue that the government has to violate many laws including its obligation to protect all its citizens if euthanasia is legalized.

\section{Right to Life and Dignity}

Even though it is not embedded as a fundamental right in a constitution or a basic right recognition, as a human being a right to autonomy, or right to die dignified when restrained would amount to violation of basic human right as it is the choice of the individual over the body which he/she possess. Dignity as a human right and its recognition around the world in International scenario as to Right to life is mentioned in various treaties $\left[{ }^{17}\right]$.

Art.21 under Indian Constitution provides for Right to life upon which every other right subsists. Right to life of one person is a single right but our constitution provides it to be double aspect, one the right to your life is yours but right to kill or ending of life depends on the government who is under the obligation or a duty to protect the life of its citizens. One aspect on which right to die cannot be considered as part and parcel of right to life is due to the fact that they destroy each other $\left[{ }^{18}\right]$.

\section{Statute in Human Right and Euthanasia}

Constitution of India guarantees Art.21 right to life now after the Aruna Ramchandra's Case right to die with dignity is also included while performing Passive euthanasia after getting informed consent from the patient prior hand. Thus, once it is a fundamental right, the base of human right given to the human being is recognised at stretch.

Prayopavesa-Hinduism accepts the concept of right to die as a human right, when the person is terminally ill or those who have no desire, or ambition or a purpose to live anymore. Jainism also considers this aspect. While in Christianity- it is a grave sin.

\footnotetext{
${ }^{17}$ Art.3 of UDHR, Art.6(1) of ICCPR, Art.2(1) of European Convention of Human Rights, 1950: Art.4(1) of American Convention on Human Rights: "Every person has the right to have his life respected. This right shall be protected by law, and, in general from the moment of conception. No one shall be arbitrarily deprived of life.", Art.6 on Conventions on the Rights of the child: "State Parties should recognize that every child has the inherent right to life.and that it shall ensure to the maximum extent possible for the survival and development of the child.", Art.10 of Convention of rights of persons with Disabilities: right to life is inherent from birth and that they can use necessary measure to ensure that it is lived full. ${ }^{18}$ Maneka Gandhi v. UOI,AIR 1978 SC 597
} 
Art.6(1) of ICCPR- allows passive euthanasia, when the medication is given to a patient to relief him/her of pain but it results in death, such would not be considered as illegal $\left[{ }^{19}\right]$. In Re quinlan case $\left[{ }^{20}\right]$ in US is one of the landmark decisions given by the SC where the girl,, Karen Quinlan was kept alive through Artificial Ventilation, the parents requested to remove so that she could have a peaceful death. The Court allowed the same. The Court observed this in light of Art. 6(1) of ICCPR $\left[{ }^{21}\right]$.

Another important case of euthanasia was $R v$ Martin $\left[{ }^{22}\right]$. Defendant was prosecuted for attempting the murder of mother who was terminally ill. The Crown said that assisted suicide violates the very nature of the sanctity of life. Wild J said"a patient has no legal right to insist upon medical intervention that would end the patient's life. Medical care may be refused by a patient, but the patient cannot insist upon medical steps that end life" $\left[{ }^{23}\right]$. Article 8 of the European Convention"everyone has the right to respect for his private life may be used for supporting the patients right to seek assistance to die."

The European Court of Human Rights used the Art. 2 of European Convention of Human Rights in Pretty $v$ United Kingdom $\left[{ }^{24}\right]:-$

"Article 2 cannot, without a distortion of language, be interpreted as conferring the diametrically opposite right, namely a right to die; nor can it create a right to self-determination in the sense of conferring on an individual the entitlement to choose death rather than life".

Lethal dose was not allowed in Germany initially and the case of Koch in 2005 prove to be a better case law as to why euthanasia was not allowed, the Husband and wife flew to Switzerland with help of an association, an assisted death the wife committed suicide. The applicant, the husband filed that it violated the government's obligation to protect one's life and the non-hearing of the petition by the administrative and domestic court amounts to violation of his right to privacy. Court held that it is violation under Art. 8 Right to respect for private and family life. The Court considered that it is upto the German Courts to examine the merits $\left[{ }^{25}\right]$.

\footnotetext{
${ }^{19}$ In Re Quinlan Case, 70 N.J. 10; 355 A.2d 647 (1976)

${ }^{20}$ Supra Note. 8

${ }^{21}$ Chewtwynd SB, Right to life,right to die and assisted suicide, (2004) Online:NCBI

22 [1992] 1 S.C.R. 838

${ }^{23}$ R v Martin 3 NZLR 69,2003

${ }^{24}$ (2346/02) [2002] ECHR 423 (29 April 2002)

${ }^{25}$ Koch V.Germany APP No.497/09, ECHR Jul 19,2012
}

From all over, euthanasia was a very much debated and discussed topic, such discussion also fell upon France while dealing with the case of Lambert and Others v. France $\left[{ }^{26}\right]$ Conseil d'Etat took a drastic decision using Art.2 of European Convention of Human Rights $\left[{ }^{27}\right]$.

Vincent Lambert is the victim and this case is filed by his parents, he suffered an head injury from an accident due to which he went into the state of coma. The application is filed against the judgement of Conseil d'Etat which relied upon the medical report by three doctors in withholding his hydration and nutrition and declared in lawful. Complaint was made against the judgement delivered by the Conseil d'Etat. The applicants opposed and contended that it violated Art.2 European Convention's Right to Life and state's obligation in protection of life. The Judgement delivered said that there is no violation of Art.2.

The Court further considered in 2005, the Conseil d'Etat, under Act of 22, April 2005 does not mention euthanasia or the right to end life or assisted suicide. Passive euthanasia is allowed when the illness is impossible to recover from. It is the primarily a duty of the state to regard the nations' legislation before confirming a decision and desire or the consent of the patient is required. No person shall be deprived of life arbitrarily is what Art.6 of European Convention Proposes. An Involuntary act would amount to violation of human right to life.

\section{Study of legislations and principles in netherlands and belgium}

2002 marked an important year for euthanasia and a conclusion to much debated field of legalisation for the Netherlands and the Belgian Parliament. Where both means-Physicians assisted suicide and euthanasia to end a life as a possible option was allowed in the

26 “Lambert \& Ors v. France, Application no 46043/14, European Court of Human Rights"

27 "1. Everyone's right to life shall be protected by law. No one shall be deprived of his life intentionally save in the execution of a sentence of a court following his conviction of a crime for which this penalty is provided by law.

2. Deprivation of life shall not be regarded as inflicted in contravention of this article when it results from the use of force which is no more than absolutely necessary:

(a) in defence of any person from unlawful violence;

(b) in order to effect a lawful arrest or to prevent the escape of a person lawfully detained;

(c) in action lawfully taken for the purpose of quelling a riot or insurrection." 
Netherlands while Belgium relied on their laws to regulate only euthanasia $\left[{ }^{28}\right]$. The Dutch had an open minded and a free discussion before the legalization of euthanasia in public spectrum, religious institutions, addressed by the courts. This brought in the inevitable, the attention of Royal Dutch Medical Association (KNMG) which from time to time prescribed guidelines for governing the act of euthanasia. Art.293 of their criminal code prohibits voluntary euthanasia-which prohibits the killing of a person at his or her request $\left[{ }^{29}\right]$. Art.294 puts an end point to assisted suicide, if violated would be punishable for a term of three years or a fine extending upto 25,000 NLG. However, these doctors had their defense under Art.40 of criminal Code which enhances the principle of force majeure, over powering force or urgency which makes them to cause the act, would amount to lesser evil[ $\left.{ }^{30}\right] .1984$ in view of the court's decisions and demand of euthanasia and practices conducted for ending a life, the Royal Dutch Medical Associations met the consensus by stating that the physician or the medical practitioner who is assisting or performing euthanasia would not be prosecuted if the duties are followed as per the requirements with due diligence. (i) the request by the patient must be voluntary, durable and persistent; (ii) the patient was fully informed about the medical condition and the prognosis, and there was no other alternative treatment available; (iii) the patient had unbearable suffering(s); and (iv) the physician had consulted with another physician $\left[{ }^{31}\right]$.

\footnotetext{
${ }^{28}$ Luc Deliens, Gerrit Van der Wal, The Euthanasia law in Belgium and the Netherlands, Lancet Journals, Volume 362, Issue 9391, P.1239-1240.

${ }^{29}$ Netherlands was one of the foremost country to establish and give the legitimate status to Euthanasia before it was full-fledged granted to the subjects under the Article 293 of Criminal Code of Netherlands it was considered that any person who terminates a person's life even with the consent of the latter will be punishable with the offence and imprisonment of 12 years.

"1. Any person who terminates another person's life at that person's express and earnest request shall be liable to a term of imprisonment not exceeding twelve years or a fifth-category fine.

2. The act referred to in the first paragraph shall not be an offence if it committed by a physician who fulfils the due care criteria set out in Article 2 of the Termination of Life on Request and Assisted Suicide (Review Procedures) Act, and if the physician notifies the municipal pathologist of this act in accordance with the provisions of Article 7, paragraph 2 of the Burial and Cremation Act."

${ }^{30}$ Raphael Cohen-Almagor, Euthanasia in Netherlands, The legal framework, Michigan State University-DCL journal of international law(2001), Volume 10, p:322.

${ }^{31}$ G.Van der Wal, R.J.Dillmann, Euthanasia inn Netherlands, BMJ Publishing group, Volume 308, p.1346-1349
}

Based on the report and guideline in 1990 the Royal Dutch Medical Association issued another notification that the physician and medical professional has immunity if they follow the "Rules of careful Practice" and also made it mandatory that any act of euthanasia or PAS a questionnaire report has to be submitted to the medical examiner, the medical examiner then sends it to the public prosecutor who decides on prosecution proceedings commencement $\left[{ }^{32}\right]$. In 2000 the legislation was passed which made Euthanasia legal and put end to all debate and discussion provided the criteria is followed. 1 . The patient must be suffering unbearable and a pain with no possibility for improvement. 2. Voluntary informed consent from should be obtained from the patient requesting help to die with all other medical remedies exhausted $\left[{ }^{33}\right]$. For the diagnosis and prognosis a second medical opinion has to be sort. The termination is then carried out by the medical professional or the physician with due care and attention, after which the report has to be sent to the municipal pathologist, specifying the cause of death, whether it is euthanasia or assisted suicide. A sentence of up to 12 years will be granted if the guidelines are not followed, and the burden of proof also lies with the regional panel which was shifted from the doctors $\left[{ }^{34}\right]$.

Belgium has a different governing scheme of euthanasia than Netherlands, most liberalized form of euthanasia law. Euthanasia Act,2002-Belgium which came into force on September 2002, this has similar criterions as mentioned in Netherlands Euthanasia Act,2002 that the euthanasia must be performed at the request of competent patient who have not been influenced by others $\left[{ }^{35}\right]$. It must be made voluntary, well considered and repeated. The disease must be unbearable or a serious incurable disorder. Since 2014 even children can opt for Euthanasia $\left[{ }^{36}\right]$. Belgium provides for Voluntary Euthanasia under Sec.2, to end life by someone other than the patient. That someone maybe a medical professional or a physician or some other person, it has not been defined and left to ambiguity. The permits the right to die with dignity and not give the right to die per se, it grants request to termination of life, doctors can object on various grounds, morally or medically.

Two procedural requirements are prescribed in the Euthanasia Act, 2002 which suggests that a fellow physician must be consulted who is independent and has no relation with the patient as well as the attending

\footnotetext{
${ }^{32}$ Natasha Cica, Euthanasia-the Australian Law in an International Context, Parliament of Australia, (1997),Online: aph.gov-Australian Govt.$$
{ }^{33} \text { Supra Note. } 8 \text {, p.323. }
$$$$
{ }^{34} I d \text {. }
$$$$
{ }^{35} \text { Euthanasia Act,2002-Belgium, Sec.3(1) }
$$$$
{ }^{36} \text { Euthanasia Act,2002-Belgium, Sec. } 2 \text { \& } 3
$$ 
medical professional [ $\left.{ }^{37}\right]$. Next would be the consultation with the patient's medical records and examine as to the patient is in fact suffering from a physical and psychological problems which is incurable and unbearable. When the attending physician is not convinced as to death in the near future for the patient a third consultant, a psychiatrist in the patient's illness must be consulted with $\left.{ }^{38}\right]$. It also suggests that one month waiting period is required before conducting euthanasia. The decision of the doctor and the patient must coincide that there are no other alternatives but death $\left[{ }^{39}\right]$. Wishes of the patient shall be discussed the relative of his choosing prior to the commencement of termination of life $\left[{ }^{40}\right]$.

After the performing Euthanasia within four working days a euthanasia registration form must be filled by the attending medical professional or a physician and submit it before the Federal control and Evaluation Committee on Euthanasia. Assisted suicide is not separately mentioned in the Belgium Euthanasia Act,2002 but the National Council of the College of Physicians in the year 2003 stated that it is equal to euthanasia and can be performed provided due care requirements are followed $\left[{ }^{41}\right]$.

For the safe societal control and evaluation, the physicians and the medical professionals on performing euthanasia have to report it to Federal Control and Evaluation Committee who upon the review determines whether it was a valid and legal case of euthanasia after following all the procedure and due care requirements $\left[{ }^{42}\right]$. If the two third of the panel feels that the legal requirements are not followed the case will be sent to the public prosecutor $\left[{ }^{43}\right]$. There also exist advance Euthanasia directive where the patient is not in sane or conscious mind to give consent, the physician after consultation with three other doctors and a written report with two witnesses not having any interest in the patient's death can proceed with performance of euthanasia. Official registration must be made in the civil registry of Municipality $\left[{ }^{44}\right]$.

\section{Euthanasia of Minors}

The Euthanasia Act, 2000 of Netherlands has special provisions in case of termination of life for children from age 12-16, which can be done in case of incurable diseases and with parental consent however

\footnotetext{
${ }^{37}$ Euthanasia Act,2000, Sec.3(1)

${ }^{38}$ Supra Note.1, p. 20.

${ }^{39}$ Euthanasia Act,2000, Sec.3(2)(2)

${ }^{40}$ Euthanasia Act,2000, Sec.3(2)(5)\&(6)

${ }^{41}$ Supra Note. 1,p. 20

${ }^{42}$ Euthanasia Act,2002-Belgium, Sec.5

${ }^{43}$ Sigrid Dierickx, Luc Deliens, Joachim Cohen,
} Kenneth chambaere,Euthanasia in Belgium: trends in reported cases between 2003 and 2013,CMAJ Journal, (Nov 1,2016), Online: NCBI

${ }^{44}$ Euthanasia Act,2002-Belgium, Sec.7 the doctor can also terminate the life without the parental consent which is a rare case scenario. For age 16-18 euthanasia can be done even without getting a specific consent from the parents $\left[{ }^{45}\right]$. In Belgium,2014 Minors were also given the eligibility to children with no age bar can opt for euthanasia but they should be capable of understanding their decision, it should also be certified by the psychiatrist or psychologist as well as supported by the parents, who has the right to veto. Same procedural format will be applicable to children as well once it is approved $\left[{ }^{46}\right]$. It is an improvement in the connotation from the parent's point of view since it would end the sufferings of the children in more legalized mechanism with the aid of medical practitioners, giving the parents peace of mind both health, physical and mental wise.

\section{Rationale behind Euthanasia in Netherlands:}

History plays an important role in understanding one's polity and form of government with culture, social standards of one country. Similarly, Belgium and Netherlands had its own popular opinion and demand from the people which it had to take into its hands. This can be evidenced in Postma case in Netherlands $\left[{ }^{47}\right]$. For physician assisted suicide a campaign was conducted for legalization, the Court held that the doctors have no compulsion upon them to prolong life and the aftermath of postma case KNMG issued a statement that medication and administration of drugs can be justified even if the end result is death. Euthanasia's first acquittal took place in 1983 where the Court of Hague in Schoonheim case stated that when there is a compelling reason of conflict between preserving the life of the patient and increase the pain and suffering of the patient, the necessity of performance of euthanasia by the doctor is justifiable $\left[{ }^{48}\right]$. Right to die with dignity is recognised in Netherlands therefore, the legislation implementation $\left[{ }^{49}\right]$.

Now that we have seen the concept of Right to life and death, Euthanasia's legality and validity comes into the picture, what is the legality of the medical assistance given during mercy killing?

\footnotetext{
${ }^{45} I d$.

46 Jo Samanta, Children and Euthanasia:Belgium's Controversial new law, Diversity and Equality in health and care, iMedPub LTD, Diversity \& Equality in Health and care, Online:Diversityhealthcare see also, $B B C$ News, Belgium minor first to be granted euthanasia, (Sept 17,2016),. Online:BBC, Also, Washington Post,Children are being euthanized in Belgium, ( Aug 6,2018)Online: Washingtonpost.

${ }^{47}$ T Sheldon,Andries Postma,BMJ Journals, (Feb 10,2007) Online: NCBI.

${ }^{48}$ Supra Note. 14 p.327-340.

${ }^{49}$ Sjef Gevers, British Medical Bulletin,1996, Issue No.2, p.326-333.
} 
Euthanasia is debated around the world, for the Hippocratic Oath taken, religiously and against the ethics which the doctor has to perform his duty. I will strictly confine this concept of legality to assisted death by doctors and nurses.

Let's take for example when a person is given the choice to terminate his treatment in England, the choice is given to the patient to decide on the stage in which the treatment process should stop regardless of the disease being a life threatening one. When the person is given the choice of ending his life in a slow deathful process why can't he be given the choice to die with dignity and at a stage which he/she chooses?

Here right to die with dignity comes into picture; a physician assisted death can end a person's life with his or her choice. With the advancement of technology, the doctors can try only maximum to sustain the life of a person, the family and the health care institutes have enormous pressure upon them to guarantee a good medical facility which is only available with costly resources. In India, Poverty rate is at its peak even with the economic growth in day to day lives in education, employment. Poverty still prevails, when a person can't die peacefully then why live a forceful life?

European Convention does say under Art.5 that inhumane or torture degrading treatment is violation of the human right. It is inhumane to prolong the life of the patient when he wants to die with dignity and peace; it will contribute not only to the inhumane treatment but will also amount to torture. Which in consequence will violate Art.5 of European Convention of Human Rights, they can be brought before the international Court.

In Netherlands, an adult of a sound mind is guaranteed the right to choose his death in case of incurable disease of patient which will be decided by the doctor, where such request to die should be made in front of two witnesses to attest. After the request is made a period of 7 days is given to the patient again to find out whether he/she wants to die, which period can be reduced by the leave of the Court $\left[{ }^{50}\right]$.

\section{Implementation of euthanasia in india}

Five Bench of the Apex Court which included Justice Dipak Misra, A.K.Sikri, A.M.Khanwilkar, D.Y.Chandrachud, and Ashok Bhushan gave recognition to passive euthanasia by granting guidelines as to acceptance of living will by the terminally ill patients.

\footnotetext{
${ }^{50} \mathrm{~S}$ Gevers, Euthanasia: law and practice in the Netherlands(1996),Online: Academiccoup
}

Justice Chandrachud mentioned that "Dying is part of Living and are quite inseparable" after the case of Gian Kaur v. state of Punjab, in Aruna Ramchandra v. UOI $\left[{ }^{51}\right] 2011$ case the SC gave permission to passive euthanasia with exceptions and strict medical guidance. When a living Will is written by the terminally ill patient in regards to his/her right to die, passive euthanasia is a viable option.

A living will, a written document which allows a patient to instruct in prior about the medical treatment to be administered on the terminally ill and when he/she is no longer able to give an express informed consent, including the aspect of withdrawing life support and when the medical board declares by all means and wholly that all lifesaving options have been exhausted then the act of passive euthanasia can be administered $\left[{ }^{52}\right]$.

Supreme Court in 2018 in the case of Aruna Shanbaug $v$ Union of India $\left[{ }^{53}\right]$ held that right to die with dignity is a fundamental right under Art.21 of the Constitution of India. The bench held that right to live with dignity is inclusive of the process of death of patient with no cure or unbearable suffering. Supreme Court allowed Passive Euthanasia after a long fight and legitimating the judgement. The court also took into its case the study of other jurisdiction.

"Further, a study of the position in other jurisdictions shows that Advance Directives have gained lawful recognition in several jurisdictions by way of legislation and in certain countries through judicial pronouncements. Though the sanctity of life has to be kept on the high pedestal yet in cases of terminally ill persons or PVS patients where there is no hope for revival, priority shall be given to the Advance Directive and the right of self-determination. In the absence of Advance Directive, the procedure provided for the said category hereinbefore shall be applicable. When passive euthanasia as a situational palliative measure becomes applicable, the best interest of the patient shall override the State interest"-CJI Deepak Misra $\left[{ }^{54}\right]$ "Now that you have decided to allow passive euthanasia, we have to evolve safeguards,"

While pronouncing the judgement the international position in UK Decisions of right to die

\footnotetext{
${ }^{51}$ Aruna Ramchandra Shanbaug v. UOI, (2011) 4 SCC 454

${ }^{52}$ Atul Yadav, Passive Euthanasia now a legal reality in India(2018), Online:thewire.

${ }^{53}$ Aruna Ramachandra Shanbaug v. UOI,IR (2011) SC 1290

${ }^{54}$ Livelaw,Breaking: Right to die with dignity a fundamental right, SC allows Passive Euthanasia and Living will,Issues Guideliness, (Mar 9,2018)Online: Livelaw.
} 
with dignity in Airedale case $\left[{ }^{55}\right]$, the legal position in United States prohibiting active euthanasia[ $\left[{ }^{56}\right]$ ECHR international Considerations and decisions was done a walk about along with Australian and Canada jurisdiction. The analysis of different jurisdiction and the legal system allows the judges to obtain knowledge as the interpreter of law to understand and give justice to the principles in the constitutional law of the land; they accommodate the knowledge to their legal system and rationale for their decisions.

Now that the Right to dignified death is legalized in India in informal norm by legal institution it is time to turn to the legislators, the democrats to make laws to govern and take governance over the same having societal control over it. The legislators have to make specifications with the definitions to the law, adjacent to the authority to control the activities of the physicians and medical professionals clearly demarcating the rights of the patients and responsibilities of the doctors to pursue euthanasia, with due care provisions by taking into balance the rights of the person to die dignified and state's interest in protection of life.

\section{Indian case laws on Right to Life}

There are various case laws which exhibit the right to live with dignity and there incurs interpretation of right to life to include or not adhere to right to die one such case law which extends the interpretation of Art.21 of Indian Constitution is the judgement of Sunil Batra v. Delhi Administration $\left[{ }^{57}\right]$ which portrayed that right to life includes all aspects which endeavours a human being to life a healthy life, which also involves right to live, sleep in peace, and in good health. Body mutilation is one of the dangerous bodily hurt and is prohibited in India so that it can't be precedent to the growing generation. Kharak Singh v. State of Uttar Pradesh $\left[{ }^{58}\right]$ : Right to live a peaceful and healthy life. It prohibits body mutilation. The above cases depicts that right to life should be accompanied by right to good health, peaceful environment and life that is lived with dignity.

\section{Right to dignity}

Right dignity is associated with humanity and the right to life. It is given the day we were born as a human right. Dignity cannot be defined in definite terms. It is an inherent right; modern words describe it to be respect of a person including the criteria of status.

\section{Indian Case laws in relation to Human Dignity}

Two important case laws paved way for the growth and expansion of interpretation to the right to life, to be inclusive and substantiate of right to die with

\footnotetext{
${ }^{55}$ Airedale Health Trust v. Bland, [1993] 1 All ER 821

${ }^{56}$ P.89 of the Judgement of Aruna Shanbaug v UOI.

${ }^{57}$ Sunil Batra v. Delhi Administration, 1980 AIR 1579

${ }^{58}$ Karak Singh v. State of UP, 1963 AIR 1295
}

dignity, since earlier days it was not allowed nor was it accepted as the life was considered to be under the ownership of the government. It was firstly given in the High Court of Bombay, State of Maharashtrav. Maruti Sripati Dubal $\left[{ }^{59}\right]$ : this case by Bombay HC held that the Right to life includes Right to die with dignity thereby removing the punishment under Sec.309 IPC. Having the factor of right to live and punishment for suicide under the government purview, it was a step towards progress of recognising the right of dying with dignity.

Following the increased popular stance, the Supreme Court of India interpreted Art.21-Right to life to be inclusive of right to die and right to death is recognised through death by dignity. P.Rathinam $v$. $U O I\left[{ }^{60}\right]$, "the division Bench of the Supreme Court held that Right to life includes Right to die and that forceful life is no life at all." It was one of milestone moments in the judiciary history having the Supreme Court which is the apex court that has to be followed by the other courts according Art.141, changed the law to view death in consonance with dignity.

This came to review under Supreme Court in the case of Gian Kaur v. State of Punjab $\left[{ }^{61}\right]$ : the Court held that Right to life does not include extinction of life under Art.21, it opposes each other thereby incompatible and inconsistent with each other.

\section{Why Euthanasia should be legalised through statute}

Every person has the right to life and the liberty which is attached with it along with the sense of public interest and security which is protected by the government but most important right which has to be inferred from the right of life would be the Right to self-determination. Every person has the right to determine how his or her life should end, life is never a property or an asset which can be owned or owed to another be it organisation or any other person, and it is definitely not the property of the State. The State is just the protector of the life for the betterment of social living and governance the people transferred from the right but only to safeguard. The State can take any measures to protect the life, and the life of others however when it comes to the act of right to die, State can take steps to prevent it as it is the guardian of life but ultimately it is the person's choice and determination of life that counts. And when it is a death bed choice, where they no longer could improve any better, it should be their right. Right which are transferred to the State to govern better are not waived by the people, there are no stated provision for the same

\footnotetext{
${ }^{59}$ State of Maharashtra v. Maruti Sripati Dubal, 1987

(1) BomCR

${ }^{60}$ P.rathinam v. UOI, 1994 AIR 1844

${ }^{61}$ Gian Kaur v. State of Punjab, 1996 AIR 946
} 
$\left[{ }^{62}\right]$. It is just a contract we made with the state, which can be revoked at any time as the rightful owners.

We exchanged our right to die from right to life for protection from the State, however the state has to work towards the best interest of the people, it is the interest that none of the subjects in a state should suffer to the maximum. When the subject is suffering from extreme disease situation it is a better option to assist the death and providing for a mechanism to end the life with dignity as also inferred from the human right of right to life rather than extending the suffering and disregarding the promise of protection of wish of the subject $\left[{ }^{63}\right]$.

The state on concern for the subjects more and it has taken upon itself that subjects belong to the state and state is the only authority to decide what to do with the people then it can balance by taking away the life through the legalization of euthanasia in precedence to the successful countries like Netherlands and Belgium, only with the consent of the affected and the medical professional reports the euthanasia can be agreed upon and allowed $\left[{ }^{64}\right]$. It does not deprive the person of his right and self-determination nor does it affect the state's interest in protecting the subjects on unacceptable consequences.

Legalizing euthanasia through a statute will render the caretakers burden and the court's burden to be reduced to the maximum because then the judges don't have to decide based on their discretion but will have to docket their decision based on the legislation and be bordered around it $\left[{ }^{65}\right]$. Sometimes if Medical treatment of a blood cancer patient fails, sustainment of life need not be done and they can refuse treatment or deny any form of feeds through tube. This is indirect form of passive euthanasia.

Statutory mechanism balances the interest of the state and the people, as the representatives of the people analyse and conclude on what is the best for the subjects and the patients wanting the euthanasia. Now that euthanasia is legalised, statutory requirements will

\footnotetext{
${ }^{62}$ Thomas Hobbes and John Locke mentions it in his Social Contract theory that men have formed a society by basing their consensus to come together to live peacefully. It is the mutual transferring of rights which is taken into account, whereby the government is formed to control its subjects. It is transfer of the natural right. John Locke believed in democratic form of government, it would be wiser to adhere to people's popular consensus.

${ }^{63}$ Supra Note. 58

${ }^{64}$ Supra Note. 27

${ }^{65}$ David Fontana, Docket Control and the Success of Constitutional Courts in Comparative Constitutional Law, Tom Ginsburg \& Rosalind Dixon, eds., Edward Elgar Publishing, (2011)
}

only make it clearer to the administrative bodies as well as to the claimants of the practitioners of euthanasia, on the grounds duties and rights guaranteed in euthanasia, the rules and procedures the administrators, the medical practitioners, the aids and family, physician should apprehend and strictly follow. In case of non-adherence will amount to violation which can be disputed as a matter of fact in the Court to get the damages, cost by the lack of negligence. When there exists no legislation, the rights can be violated easily; human rights will be in question as there is no definite procedure or dispute mechanism for the patients and the aggrieved family members to go.

Even though this is a subject that is not of main importance it is necessary to examine the role of judiciary and their decision in absence of legislation, sometimes discretion used by the judiciary does not favour the people it is serving upto, sometimes the consequences are grave. Too much autonomy and concentration of power in a single hand that does not have the accountable character unlike the legislature lead to tyranny of the judiciary. It can have the discretion in deciding the case laws, setting up the guidelines, having the role of playing judicial activism. It may overstep its bounds and do the activities of the legislature. So it is better to bring the statute for the governance of euthanasia.

\section{CONCLUSION AND SUGGESTION}

As Tushnet and Vicki C. Jackson $\left[{ }^{66}\right]$ in their comparative Constitutional law articles say, like a traveller we travel and wish to obtain knowledge and know the systems and institutions with their functions of other nations. Bricolage is done by picking up the necessity useful values and system models for the particular domestic laws of the land in concurrence with their legal system, values, culture, and polity. We can see in Netherlands and in Belgium that with advent of demand for euthanasia, the legislators and the judiciary paved way for legalisation to adopt as per their systematic changes with defined concepts, requirements of due care and principle requirement stating the rights and responsibilities of the patient's and Life terminators. Guiding them with penalties and criteria thus balancing the right and safety of the individual and the state's responsibility towards life. The state further steps in to take action to review and approve the act of euthanasia by the medical professionals and physicians through Regional Review committees, Municipal Committees in Netherlands and the Federal Control and Evaluation Committee on Euthanasia in Belgium, who in case of violation of due care procedure send the report to the public prosecutor to prosecute on behalf of the state in protecting the life and state interest. By protection of this does not bar the self determination of

\footnotetext{
${ }^{66}$ Vicki C.Jackson, Comparative Constitutional Law: Methodologies,Harvard, Penn State International Law Review, Vol. 28, p. 319, 2010.
} 
the right to die with dignity, if valued reason arrives and approved by the doctors and professional euthanasia can be carried out. India is new in granting approval to Euthanasia, only passive in nature to the ill terminated people having no scope of recovery; it needs a model for development of law and to legitimate the process of euthanasia. The model law can be taken from all over the world but one of the best administrations of euthanasia with safeguards and balancing interest would be Netherlands and Belgium. It is up to the legislators as mentioned earlier to choose according to the legal system and polity of the land, paving way for conversation and interaction, bricolaging process around the world for better principles, values, legal system, institution, law, rules and regulation to be guided upon. But what would be more interesting will be a global law which is accepted by all the countries and be signatories to the act of euthanasia.

The conclusion can be drawn from the have cases that the light of human rights embedded in the conventions does not say that right to life includes right to die. Even though autonomy is given to sovereign state to legalize euthanasia or passively accept euthanasia, Right to die with Dignity is an emerging factor and has to be considered while accepting Right to life. Right to die with dignity is a human right and when death occurs in a natural way it is incoherent to put a full stop or prolong the life of a person wasting the resources and materials, with the cost of the government. 